\title{
Production and characterization of amplified tumor-derived cRNA libraries to be used as vaccines against metastatic melanomas Jean-Philippe Carralot ${ }^{1,2}$, Benjamin Weide ${ }^{3}$, Oliver Schoor ${ }^{2}$, Jochen Probst ${ }^{1,2}$, Birgit Scheel ${ }^{1}$, Regina Teufel ${ }^{1}$, Ingmar Hoerr ${ }^{1}$, Claus Garbe ${ }^{3}$, Hans- Georg Rammensee ${ }^{2}$ and Steve Pascolo*1,2
}

Address: ${ }^{1}$ CureVac, Paul Ehrlich Strasse 15, 72076 Tübingen, Germany, ${ }^{2}$ University of Tübingen, Institute for Cell Biology, Department of Immunology; Auf der Morgenstelle 15; 72076 Tübingen, Germany and ${ }^{3}$ Section for Dermatological Oncology, Tübingen University Hospital, Liebermeisterstraße 25, 72076 Tübingen, Germany

Email: Jean-Philippe Carralot - carralot@curevac.de; Benjamin Weide - bnweide@med.uni-tuebingen.de; Oliver Schoor - oliver.schoor@unituebingen.de; Jochen Probst - jochen.probst@student.uni-tuebingen.de; Birgit Scheel - bs@curevac.de; Regina Teufel - rt@curevac.de; Ingmar Hoerr -ih@curevac.de; Claus Garbe - claus.garbe@med.uni-tuebingen.de; Hans-Georg Rammensee - rammensee@uni-tuebingen.de; Steve Pascolo* - steve.pascolo@uni-tuebingen.de

* Corresponding author

Published: 22 August 2005

Genetic Vaccines and Therapy 2005, 3:6 doi:10.1186/1479-0556-3-6

This article is available from: http://www.gvt-journal.com/content/3/I/6

(c) 2005 Carralot et al; licensee BioMed Central Ltd.

This is an Open Access article distributed under the terms of the Creative Commons Attribution License (http://creativecommons.org/licenses/by/2.0), which permits unrestricted use, distribution, and reproduction in any medium, provided the original work is properly cited.

\section{Abstract}

Background: Anti-tumor vaccines targeting the entire tumor antigen repertoire represent an attractive immunotherapeutic approach. In the context of a phase I/II clinical trial, we vaccinated metastatic melanoma patients with autologous amplified tumor mRNA. In order to provide the large quantities of mRNA needed for each patient, the Stratagene Creator ${ }^{\mathrm{TM}}$ SMART ${ }^{\mathrm{TM}}$ CDNA library construction method was modified and applied to produce libraries derived from the tumors of 15 patients. The quality of those mRNA library vaccines was evaluated through sequencing and microarray analysis.

Results: Random analysis of bacterial clones of the library showed a rate of $95 \%$ of recombinant plasmids among which a minimum of $51 \%$ of the clones contained a full-Open Reading Frame. In addition, despite a biased amplification toward small abundant transcripts compared to large rare fragments, we could document a relatively conserved gene expression profile between the total RNA of the tumor of origin and the corresponding in vitro transcribed complementary RNA (cRNA). Finally, listing the 30 most abundant transcripts of patient MEL02's library, a large number of tumor associated antigens (TAAs) either patient specific or shared by several melanomas were found.

Conclusion: Our results show that unlimited amounts of cRNA representing tumor's transcriptome could be obtained and that this cRNA was a reliable source of a large variety of tumor antigens. 


\section{Background}

The identification by van der Bruggen et al. [1] of the first tumor associated (TAA) antigen recognized by specific cytotoxic T lymphocytes (CTLs) in melanoma patients boosted the development of anti-cancer immunotherapy strategies. During the last years, vaccination protocols targeting differentiation antigens (MART-1/Melan-A [2,3], gp100 [4], Tyrosinase [5,6]) or cancer-testis antigens (MAGE [1,7], NY-ESO1 [8]) were tested and showed encouraging results [9-11].

However, a growing body of evidence suggests that, instead of using defined antigens, targeting the whole spectrum of tumor antigens would represent an alternative, potentially more efficacious method [12-14]. Indeed, the use of total tumor material for vaccination allows the development of $\mathrm{B}$ and $\mathrm{T}$ cells directed against a large variety of known but also unknown TAAs [15]. In addition, stimulating such a large spectrum of specific effectors directed against multiple epitopes restricted by diverse HLA class I and II types would reduce the risk of tumor escape through antigen loss or MHC downregulation [1619]. Finally, another advantage of the whole tumor approach is that, in an autologous setting, patient's TAAs eventually stemming from tumor-specific somatic mutations could be targeted [20,21].

In order to vaccinate patients with the whole spectrum of TAAs, several methods were developed. In 1998, Soiffer $e t$ al. [22] disclosed the results obtained by vaccinating patients with autologous irradiated tumor cells engineered to produce GM-CSF. The same year, Nestle et al. [23] showed partial or complete tumor remissions in six melanoma patients vaccinated with dendritic cells (DC) loaded with autologous tumor lysate. Alternatively, Boczkowski et al. [24] reported that mouse DCs pulsed in vitro with tumor RNA could trigger an anti-tumor immunity in vivo. Several groups further developed and optimized those different strategies [25-27] but faced the limitation imposed by the requirement of large amounts of tumor tissue for lysate preparation or for sufficient RNA yields extraction. In order to overcome this drawback, Boczkowski et al. [28] modified the SMART method (BD Biosciences Clontech, Palo Alto, CA) in order to in vitro transcribe tumor cDNA and performed therefore a onestep amplification of tumor mRNA. Transfected into antigen presenting cells (APCs), this amplified cRNA was shown in vitro to induce anti tumor immunity $[29,30]$. As an alternative vaccination method, Hoerr et al. [31] demonstrated the capacity of mRNA coding for defined antigens or of total cRNA to trigger an antigen-specific immune response after direct intra-dermal injections of the ribonucleic acid. Similarly, Granstein et al. [15] showed protection against $\mathrm{S} 1509$ tumor cells in mice that received three intradermal injections of total RNA extracted from S1509 cells. Although still marginally studied compared to mRNA-loaded DC vaccines, the direct injection of mRNA represents a technology that offers the important advantage to circumvent the time and money consuming steps of generation of DCs.

In 2003, we initiated the first phase I/II clinical study to test the feasibility, safety, and efficacy of a vaccine composed of autologous amplified tumor mRNA in stage III/ IV patients with metastatic melanoma (The detailed evaluation of the toxicity, clinical and immunological efficacy of this treatment will be reported in a following manuscript). Fifteen patients received from 3 to 16 intradermal injections of $200 \mu \mathrm{g}$ of amplified autologous tumor cRNA. The amount of injected RNA was limited by the maximal intradermal injection volume $(100 \mu \mathrm{l})$ and set according to the preclinical results which indicated that a concentration of ca. $0.8 \mu \mathrm{g} / \mu \mathrm{l}$ was leading to a good gene transfer. The injection's schedule consisted in applications every two weeks of four injections and then once every month. It was decided empirically since no previous data on the toxicity and efficacy of this immunization method are available in humans. In mice one injection was shown to be sufficient to trigger an immune response [31]. However, in cancer patients, a sustained stimulation of the immunity is probably requested in order to get an efficient anti-tumor immune response. According to this protocol, the required amount of cRNA for a complete therapy was between 0.6 and $3.2 \mathrm{mg}$ per patient (table 1). In order to get unlimited amounts of product, a new method for the amplification of the tumor mRNA was developed. Briefly, a cDNA library was generated from tumor RNA using the SMART (Switch Mechanism At the 5'end of RNA Templates) system (BD Clontech) and then was cloned in our RNActive $^{\mathrm{TM}}$ vector (CureVac $\mathrm{GmbH}$ ), amplified in Escherichia coli, and finally transcribed in vitro. As opposed to the protocol described by Boczkowski et al. [28] in which the PCR-amplified tumor cDNA library was directly used as template for the in vitro transcription (resulting in limited cRNA amounts), the method applied in our laboratory provided us with unlimited amounts of the tumorderived cRNA.

Whereas the SMART method was reported to maintain the relative levels of RNAs contained in the original transcriptome regardless of their size or their baseline expression [32], the cloning step in E. coli was on the contrary described to introduce a bias favoring short fragments [33]. We thus analyzed the quality of the produced amplified-mRNA libraries to be used as a vaccine in melanoma patients. Several clones randomly picked-up within the produced libraries were analyzed by PCR and sequenced. In addition, the gene expression profiles of two metastases were compared to their corresponding cRNA-libraries. 
Table I: Summary of mRNA libraries and clone analysis. In the case of MELI4, total RNA was extracted from $\sim 5 \times 10^{4}$ pleural tumor cells (NA: Not applicable)

\begin{tabular}{|c|c|c|c|c|c|c|c|}
\hline \multicolumn{2}{|c|}{ Patients } & \multirow{2}{*}{$\begin{array}{c}\begin{array}{c}\text { Weight of } \\
\text { tumor sample } \\
\text { (mg) }\end{array} \\
32.4\end{array}$} & \multirow{2}{*}{$\begin{array}{c}\begin{array}{c}\text { Quantity of } \\
\text { extracted } \\
\text { total RNA } \\
(\mu \mathrm{g})\end{array} \\
9.4\end{array}$} & \multirow{2}{*}{$\begin{array}{c}\begin{array}{c}\text { Number of } \\
\text { clones (cfu) }\end{array} \\
1 \times 10^{5}\end{array}$} & \multirow{2}{*}{$\begin{array}{c}\begin{array}{c}\text { Size range of } \\
\text { analyzed } \\
\text { clones (nt) }\end{array} \\
500-4000\end{array}$} & \multirow{2}{*}{$\begin{array}{c}\begin{array}{c}\text { Quantity of } \\
\text { mRNAlibrary } \\
\text { prepared } \\
\text { (mg) }\end{array} \\
2.8\end{array}$} & \multirow{2}{*}{$\begin{array}{c}\begin{array}{c}\text { Number of } \\
\text { injection } \\
\text { performed }\end{array} \\
10\end{array}$} \\
\hline I & MELOI & & & & & & \\
\hline 2 & MEL02 & 33 & 10.5 & $1 \times 10^{5}$ & $200-8000$ & 5.0 & 12 \\
\hline 3 & MEL03 & 33.6 & 26.3 & $5 \times 10^{5}$ & $250-1000$ & 1.9 & 6 \\
\hline 4 & MEL04 & 38 & 36.7 & $2 \times 10^{5}$ & $400-3500$ & 3.6 & 8 \\
\hline 5 & MEL05 & 85 & 14.2 & $2 \times 10^{5}$ & $500-1000$ & 5.0 & 13 \\
\hline 6 & MEL06 & 60 & 115.2 & $3 \times 10^{5}$ & $300-1200$ & 4.0 & 16 \\
\hline 7 & MEL07 & 76 & 70.5 & $5 \times 10^{5}$ & $500-1200$ & 2.8 & 7 \\
\hline 8 & MEL08 & 34.1 & 60.9 & $3 \times 10^{5}$ & $500-1200$ & 5.3 & 16 \\
\hline 9 & MEL09 & 95 & 84 & $4 \times 10^{4}$ & $350-800$ & 4.5 & 10 \\
\hline 10 & MELIO & 78.7 & 62.5 & $2 \times 10^{5}$ & $600-1200$ & 4.2 & 16 \\
\hline II & MELI I & 77.3 & 9.56 & $3 \times 10^{5}$ & $400-1000$ & 2.7 & 3 \\
\hline 12 & MELI 2 & 34.3 & 15.4 & $6 \times 10^{4}$ & $400-1200$ & 3.9 & 10 \\
\hline 13 & MELI 3 & 72 & 9.14 & $2 \times 10^{5}$ & $750-2000$ & 4.4 & 16 \\
\hline 14 & MELI 4 & NA & 13.2 & $1 \times 10^{5}$ & $400-10000$ & 1.8 & 4 \\
\hline 15 & MELI 5 & 60 & 41.5 & $3 \times 10^{5}$ & $500-4000$ & 4.1 & 8 \\
\hline \multicolumn{2}{|c|}{ Average } & 57.8 & 38.6 & $2 \times 10^{5}$ & $450-3250$ & 3.7 & 10 \\
\hline
\end{tabular}

\section{Results and discussion Tumor-derived mRNA library quality}

Total RNA was extracted form 15 fresh melanoma tissues. It was then used to generate cDNA libraries according to the SMART protocol (BD Clontech, Palo Alto, CA). The obtained cDNA libraries were ligated into the RNActive ${ }^{\mathrm{TM}}$ vector (CureVac $\mathrm{GmbH}$, Tübingen, Germany) containing the mRNA stabilizing sequences of $5^{\prime}$ and 3 ' UnTranslated Regions (UTR) from $\beta$ - and $\alpha$-globin respectively $[34,35]$. Moreover, this vector introduced a 70 A poly(A) tail further enhancing mRNA translation potential (data not shown). RNActive ${ }^{\mathrm{TM}}$ libraries were transformed into ultracompetent $E$. coli. The total primary transformant numbers were ranging from $6 \times 10^{4}$ to $5 \times 10^{5}$ clones with an average number of $2 \times 10^{5}$ (table 1 ). In order to determine the ligation efficiency, 24 clones per library were randomly picked up and submitted to 35 PCR cycles using primers flanking the cDNA insertion sites. Ninety-eight percent of the 312 analyzed clones had an insert with sizes ranging from $200 \mathrm{bp}$ to $10 \mathrm{kbp}$ (data not shown). In order to further test the quality of the libraries, plasmid DNA of 9 clones randomly picked up were extracted for 5 'end sequencing (Figure 1). Out of the 112 readable sequences, 2 clones had no insert confirming the $2 \%$ rate of self-ligation found by PCR analysis. Among the remaining 110 clones, $3(3 \%)$ showed sequences classified as aberrant with insert sizes inferior to $50 \mathrm{bp}$ probably corresponding to recombination events. The other 107 sequences were analyzed BLAST [36] (Basic Local Alignment Search Tool) using the nr database. About half of the clones (51\%) cor- responded to full Open Reading Frames (ORFs) of annotated sequences. The other sequences were homologous to ESTs (Expressed Sequence Tags) coding for potential proteins with unknown functions. Full-length clone sizes ranged from 344 to $5925 \mathrm{bp}$ with an average size of 1395 bp correlating with the average insert size of $1.4 \mathrm{~kb}$ in cDNA libraries described by Draper et al. [37]. Interestingly, $28 \%$ of the clones which aligned to annotated ORFs (14\% of all sequenced clones) were tumor related genes (for instance S100 Calcium binding protein A4metastasin [38]), or genes reported to be overexpressed in tumors (for instance Laminin receptor [39]). This observation fitted with the objective of using the cRNA libraries as anti-tumor vaccines.

\section{Relative representation of transcripts}

In order to determine whether a bias was introduced by the amplification protocol, the relative gene expression in extracted total RNA from two metastases was compared to the relative gene expression in the corresponding amplified cRNA libraries. Biotin-labeled complementary RNA of tumor total RNA and of amplified cRNA libraries from patients MEL02 and MEL10 were generated using the Affymetrix eukaryotic sample and array processing standard procedure and hybridized on HG-U133A microarrays. According to the Microarray Analysis Suite 5.0 software (MAS 5.0; Affymetrix), $34 \%$ and $36 \%$ of the genes that were reported as "present" in the tumor total RNA were also detected as "present" in the amplified libraries of patients MEL02 and MEL10 respectively (Theses 


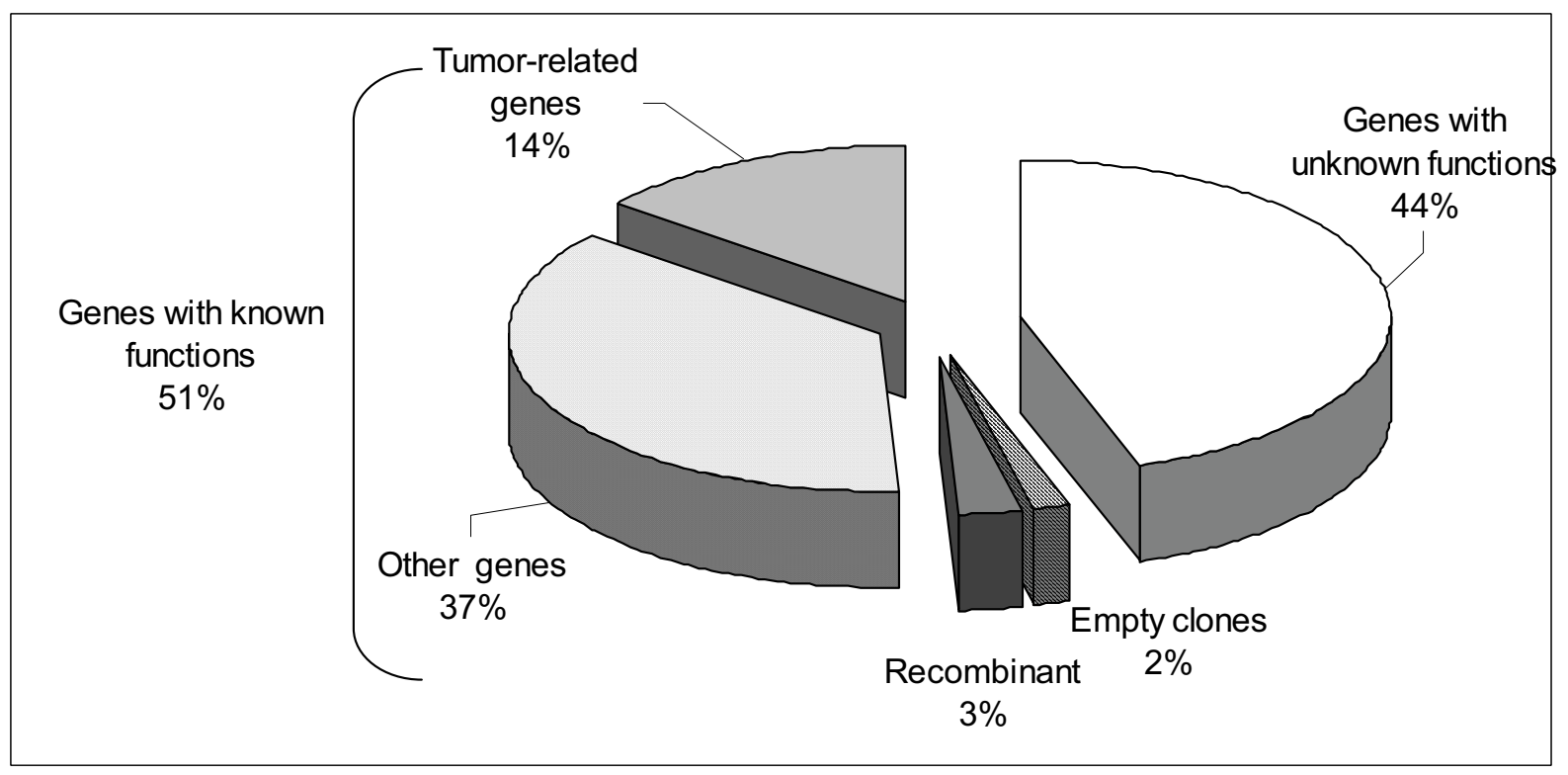

\section{Figure I}

BLAST analysis of sequenced clones. Nine clones per library were randomly picked up and their plasmid DNA was sequenced using a T7 promoter primer. Readable sequences $(n=112)$ were submitted to a BLAST analysis and their relative distribution plotted.

transcripts are qualified as "recovered" in the following). The other transcripts reported by the Microarray Analysis Suite 5.0 software as "present" in tumor's mRNA but as "absent" in the corresponding cRNA library were termed as "lost". In order to determine the factors influencing the biased amplification of genes, the size distributions of "lost" and "recovered" transcripts were compared and plotted in figure 2A. For both patients MEL02 and MEL10, the average size distribution of "recovered" genes (2218 and $1965 \mathrm{nt}$ respectively) was significantly lower ( $t$ test, $P$ $<0.0001)$ than the average size of transcripts lost during the amplification process (2894 and 3222 nt respectively). This suggests a biased amplification disfavoring large fragments as observed by Wellenreuther et al. [33]. In addition, the fluorescence values in the original tumor of genes reported as "recovered" and "lost" in the cRNA were compared as shown in figure $2 \mathrm{~B}$. Average signals of 2711 and 3709 for MEL02 and MEL10 respectively were observed for the genes present in the cRNA library and thus preserved during the process. In contrast, the genes "lost" during amplification had an average signal of only of 708 and 1174 for patients MEL02 and MEL10 respectively. These values were significantly lower $(t$ test, $P<$ 0.0001 ) than those found for the group of "recovered" genes. Thus, transcripts of higher abundance in the origi- nal tumor were preferentially preserved during the amplification process whereas mRNAs of lower abundance were eventually lost.

The fluorescence signal intensities of the genes reported as "present" in both the tumor and the corresponding cRNA libraries were plotted in figure 3 . The correlation factors to a linear regression were 0.55 and 0.42 for patients MEL02 and MEL10 libraries respectively, confirming that the mRNA amplification was quite heterogeneous. However, in the group of "recovered" transcripts no significant correlation was evidenced between the transcript size or their signal intensity in the tumor of origin and their amplification factor during the cloning (data not shown).

\section{Patient-specific gene expression}

In order to evaluate the relevance of the autologous approach, signal intensities for the genes present in metastases of MELO2 and MEL10 were compared in figure 4. As expected, the two melanoma samples were quite similar with a correlation coefficient to a linear regression of 0.75 for the 6693 genes shared between the two tumors. However, the two tissues showed specific profiles with 3222 and 483 mRNA transcripts expressed only in patient's MEL02 and MEL10 metastasis respectively. These patient- 
A
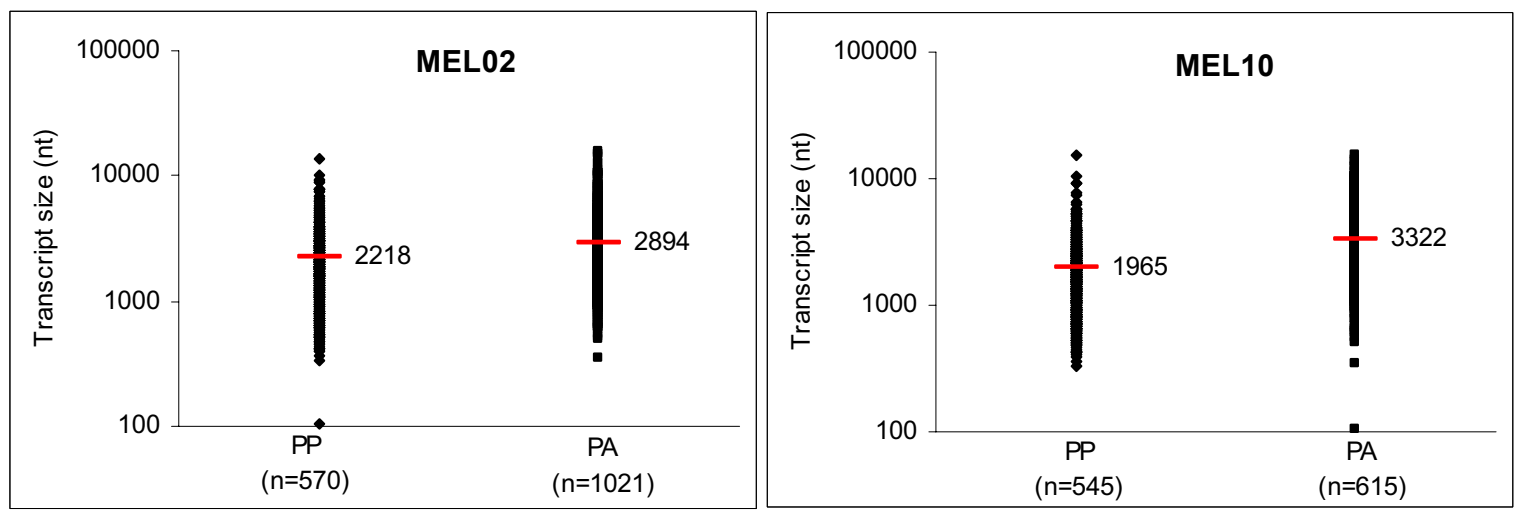

B
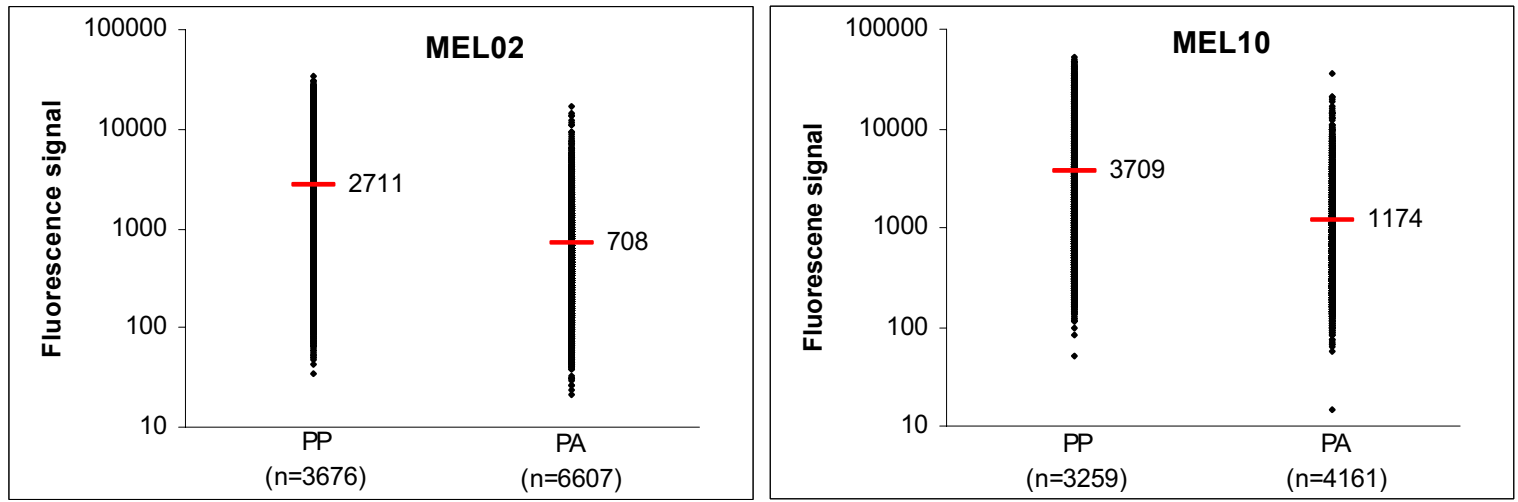

Figure 2

Comparison of sizes and fluorescence signal intensities in the original tumor sample for "lost" and "recovered" transcripts. A. The sizes of transcripts Present in tumor's total RNA and reported as Present (PP) or Absent (PA) in the cRNA library of MEL02 and MELI 0 patients were plotted. The average size of "recovered" genes was significantly lower ( $t$ test, $P<0.000 I$ ) than the average size of "lost" genes. B. The fluorescence signals of genes "Present" in the original tumor were compared for the transcripts reported as Present (PP) or Absent (PA) in the corresponding mRNA libraries. The group of "recovered" genes showed a significantly higher $(t$ test, $P<0.000 I)$ mean signal than the group of genes "lost" during the library production.

specific antigens might represent particularly interesting immunological targets [13] and argue for the injection of autologous tumor cRNA rather than the use of cRNA library derived from tumor cell lines as a vaccine.

\section{Several tumor antigens are present in the cRNA libraries}

The transcripts showing the highest fluorescence signals in the injected cRNA library were listed in Table 2 for patient MEL02. Among the 30 genes displaying the highest signals likely representing most abundant transcripts,
13 have already been described as being involved in tumor genesis or observed as being overexpressed in different cancer types. The well-defined and widely used tumor antigen Melan-A was found as one of the most abundant transcripts showing the relevance of cRNA libraries as melanoma vaccines. In addition, the presence in the injected library of many other "tumor-related" antigens rarely used in vaccines targets highlights the potential of such a product to vaccinate patients against a large panel of TAAs. 

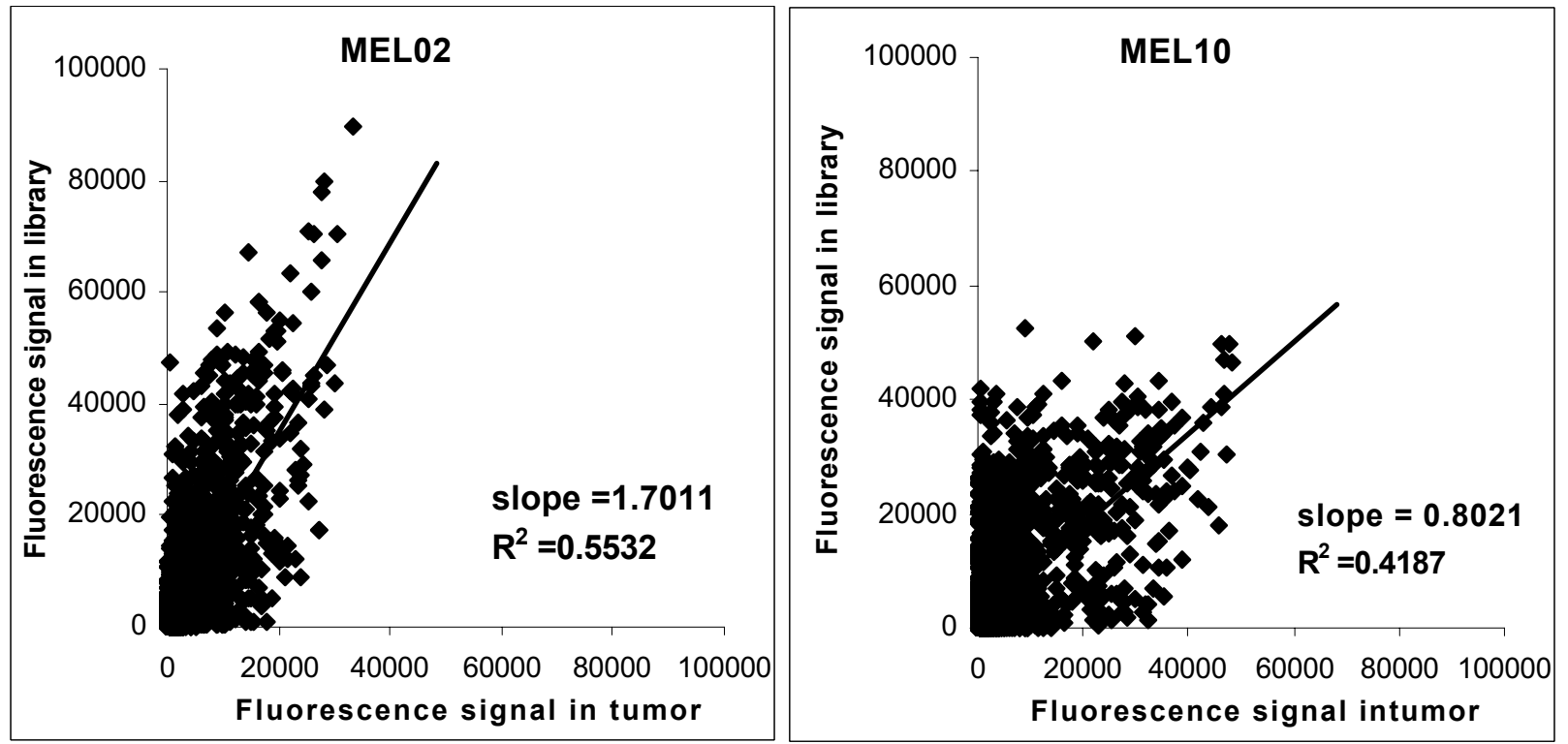

Figure 3

Correlation of signal intensities in tumor and corresponding mRNA libraries for patients MEL02 and MELI0. Fluorescence signals in original metastases and amplified tumor cRNA libraries for patients MEL02 and MELI0 were compared for all genes reported as "Present" in the library by MAS 5.0 software.

\section{Conclusion}

In order to vaccinate metastatic melanoma patients with autologous amplified tumor-derived cRNA, fifteen libraries were produced using a modified SMART method. Despite a heterogeneous amplification of tumor genes, this method provided us with an unlimited source of tumor and patient specific TAAs. Indeed, the microarray analysis of the libraries indicated the presence of high copy numbers of well-known tumor associated antigens such as Melan-A but also of abundant tumor-related antigens scarcely targeted in immunotherapy. Although not addressed in the present work, this method might also allow the targeting of tumor-specific mutations. These features makes of the amplification of tumor mRNA the method of choice to easily obtain unlimited amounts of RNA coding for patient's specific TAAs that can be applied as anti-tumor immunotherapy.

\section{Materials and methods \\ Tumor samples}

Immediately after surgery, metastatic tissues from fully informed patients (Ethic committee approval Nr.: 269/ 2002) were chopped in $\sim 0,1 \mathrm{~cm}^{3}$ pieces, and submerged in RNAlater solution from Ambion (Hungtingdon, UK), and stored at $4{ }^{\circ} \mathrm{C}$ until histological identification as melanoma by an experienced pathologist.

\section{Tumor total RNA extraction}

Total RNA was extracted from tumors using the RNeasy mini kit from Qiagen (Hilden, Germany) following the instructions of the provider. Briefly, 15 to $30 \mathrm{mg}$ samples placed in a $2 \mathrm{ml}$ eppendorf tube were snap-frozen in a liquid nitrogen bath and disrupted with micropistils from Eppendorf (Hamburg, Germany). Tumor powder was resuspended in RLT buffer, homogenized through a 20gauge needle and digested with $200 \mu \mathrm{g}$ of proteinase $\mathrm{K}$ (Qiagen) at $55^{\circ} \mathrm{C}$ during $10 \mathrm{~min}$. Samples were then clarified, loaded on RNeasy mini columns, washed and finally eluted in $50 \mu \mathrm{l}$ of RNAse-free water. RNA was quantified by U.V spectrophotometry $\left(\right.$ O. $D_{260} / O . D_{280}$ ratio was over 1.8 in all cases) and analyzed on a $1,2 \%$ formaldehyde/agarose gel.

\section{cDNA library generation}

cDNA libraries of tumor total RNA were generated using the slightly modified Creator $^{\text {тM }}$ SMART $^{\text {тм }}$ PCR CDNA library construction kit from BD Biosciences Clontech (Heidelberg, Germany). Briefly, $1 \mu \mathrm{g}$ of total RNA was reverse transcribed using SMART IV ${ }^{\mathrm{TM}}$ and CDS III/3' oligo- 


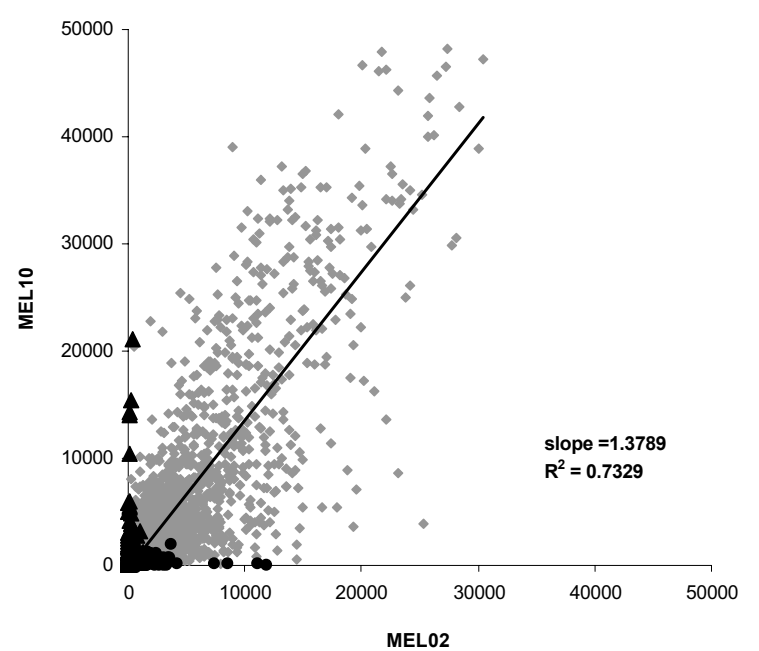

Figure 4

Correlation of fluorescence of genes present in tumors of patients MELO2 and MELI O. Fluorescence signals of patients MELO2 and MELIO tumor transcripts reported by MAS 5.0 software as present in both samples (6993 genes, $\bullet$ ), only in MEL02 metastasis (3222 genes, $\bullet$ ) or only in MELI0 melanoma (483 genes, $\mathbf{A}$ ).

$\mathrm{dT}$ primers provided by the manufacturer. After termination of the reaction, $2 \mu \mathrm{l}$ of cDNA were amplified using the Advantage 2 PCR kit (BD Biosciences Clontech). DNA polymerase was then inactivated with proteinase $\mathrm{K}$ and the cDNA library was digested with $200 \mathrm{U}$ of Sfi I enzyme. cDNA libraries were then gel-purified on an $1 \%$ agarose gel and fragments from $300 \mathrm{bp}$ to $10 \mathrm{kbp}$ were extracted using E.Z.N.A. ${ }^{\mathrm{Tm}}$ Gel Extraction kit from Peqlab GmbH (Erlangen, Germany). After precipitation, the cDNA library was ligated to dephosphorylated Sfi I-digested RNactive $^{\mathrm{TM}}$ vector provided by CureVac GmbH (Tübingen, Germany) in three separated reactions to optimize vector/ insert ratios.

\section{Cloning}

The three ligation products were used to transform XL10Gold ultracompetent cells from Stratagene (Heidelberg, Germany). For analysis, 1 and $10 \mu \mathrm{l}$ of transformation broth were plated on $2 \mathrm{LB}$-ampicillin agar plates and, after overnight culture at $37^{\circ} \mathrm{C}$, the number of clones was counted. The inserts of 8 clones per transformation were amplified by PCR using primers flanking the insertion sites and amplicons were analyzed on a $1 \%$ agarose gel. Libraries having more than $10^{4}$ clones $/ \mathrm{ml}$ and less than $20 \%$ of non recombinant clones, were amplified in three $300 \mathrm{ml}$ maxicultures in 2X LB-ampicillin medium during
$20 \mathrm{~h}$ at $33^{\circ} \mathrm{C}$ in order to limit uneven amplification of clones.

\section{DNA preparation and linearization}

Maxicultures were pooled, centrifuged down at $5000 \mathrm{rpm}$ for $10 \mathrm{~min}$ and plasmid DNA was extracted using EndoFree Plasmid Maxi (Qiagen). After precipitation, 100 $\mu \mathrm{g}$ of cDNA library were digested with $100 \mathrm{U}$ of Not I enzyme. After phenol/chloroform extraction and ammoniumacetate precipitation, linearized cDNA libraries were resuspended in RNAse-free water, quantified by U.V. spectrophotometry $\left(\mathrm{O}^{-\mathrm{D}_{260}} / \mathrm{O} \mathrm{D}_{280}\right.$ ratio was over 1.8 in all cases) and analyzed on $1 \%$ agarose gel.

\section{cRNA In vitro transcription}

Twenty to hundred micrograms of linear cDNA library were in vitro transcribed using T7 mRNA Optikit from CureVac GmbH. After mRNA synthesis, DNA template was digested with 40 to $100 \mathrm{U}$ of recombinant DNAse I purchased from Ambion. mRNA was then LiCl precipitated, phenol/chloroform purified, $\mathrm{NaCl}$ precipitated, and finally resuspended in PBS. cRNA was filter sterilized $(0,2 \mu \mathrm{m})$, heat denatured at $80^{\circ} \mathrm{C}$ for $10 \mathrm{~min}$ before final sterile aliquoting. cRNA was quantified by U.V spectrophotometry $\left(\mathrm{O}^{\mathrm{D}} \mathrm{D}_{260} / \mathrm{O} \mathrm{D}_{280}\right.$ ratio was over $1.8 \mathrm{in}$ all cases) and analyzed on 1.2\% formaldehyde/agarose gel. Sterility of cRNA was checked by inoculating LB medium (in all cases, no bacterial growth was observed after 4 days at $37^{\circ} \mathrm{C}$ ) and endotoxin content was determined using Bio-Whittaker (Verviers, Belgium) LAL assay kit (endotoxin content was always below $7 \mathrm{EU} / \mathrm{ml}$ ).

\section{Clone sequencing}

For each library, 3 colonies per transformation were randomly picked-up with a pipette tip and used to inoculate $3 \mathrm{ml}$ of LB-ampicillin medium. After overnight culture at $37^{\circ} \mathrm{C}$, plasmid DNA was extracted using E.Z.N.A miniprep kit (Peqlab). Clone sequencing was performed using the $\mathrm{ABI}$ Big Dye and a $\mathrm{T} 7$ promoter primer. Sequences were purified on Autoseq. G-50 columns (Amersham Pharmacia Biotech, Freiburg, Germany), run on a 310 Genetic Analyzer from ABI PRISM ${ }^{\mathrm{TM}}$ (Applied Biosystems, Darmstadt, Germany) and analyzed with the Sequencing Analyzing 3.4.1 software (ABI PRISM). Finally, the BLAST algorithm [36] was used to identify matches to known genes.

\section{Microarray analysis}

Expression analysis of total tumor RNA and amplified tumor cRNA was performed on HG-U133A microarrays from Affymetrix (High Wycombe, UK) according to the manufacturer's eukaryotic sample and array processing standard procedure [40], which is based on the IVT method originally described by Van Gelder et al. [41].

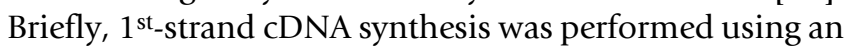


Table 2: List of the thirty transcripts showing the highest fluorescence signals in MEL02 amplified cRNA library

\begin{tabular}{|c|c|c|c|}
\hline & Title & Symbol & Observations \\
\hline I & Ribosomal protein L23a & RPL23a & \\
\hline 2 & Eukaryotic translation elongation factor I alpha I & EEFIAI & \\
\hline 3 & Ribosomal protein S3A & RPS3A & \\
\hline 4 & RNase A family, I (pancreatic) & RNASEI & \\
\hline 5 & Peptidylprolyl isomerase A, cyclophilin A & PPIA & Overexpressed in several cancers [42] \\
\hline 6 & Ribosomal protein S23 & RPS23 & \\
\hline 7 & Ribosomal protein L39 & RPL39 & \\
\hline 8 & Melan-A & MLANA & Melanoma differentiation antigen [2] \\
\hline 9 & Ribosomal protein L3I & RPL3I & \\
\hline 10 & Cytochrome $\mathrm{c}$ oxidase subunit Vlc & $\mathrm{CO} 6 \mathrm{C}$ & Overexpressed in carcinomas [43] \\
\hline 11 & Ribosomal protein L7 & RPL7 & Overexpressed in gliomas [44] \\
\hline 12 & Ribosomal protein L37a & RPL37A & \\
\hline 13 & Ribosomal protein $\mathbf{S 2 9}$ & RPS29 & \\
\hline 14 & Secreted phosphoprotein I, osteopontin & SPPI & Important for tumorgenesis [45] \\
\hline 15 & Calmodulin 2 & CALM2 & Overexpressed in several cancers [42] \\
\hline 16 & Ribosomal protein SII & RPSII & \\
\hline 17 & "Ribosomal protein S4, X-linked" & RPS4X & \\
\hline 18 & Nascent-polypeptide-associated complex alpha & NACA & Overexpressed in gliomas [44] \\
\hline 19 & Ribosomal protein L23a & RPL23A & Involved in tumor proliferation [46] \\
\hline 20 & ATP synthase, mitochondrial F0 complex, subunit $g$ & ATP5L & \\
\hline 21 & Tubulin, alpha, ubiquitous & K-ALPHA-I & Overexpressed in breast cancers [47] \\
\hline 22 & NADH dehydrogenase (ubiquinone) I alpha subcomplex & NDUFA4 & \\
\hline 23 & Ribosomal protein S27a & RPS27A & Overexpressed in breast cancers [48] \\
\hline 24 & Beta-2-microglobulin & B2M & \\
\hline 25 & H2A histone family, member $Z$ & H2AFZ & Overexpressed in several cancers [42] \\
\hline 26 & SRY (sex determining region Y)-box 4 & Sox4 & Overexpressed in lung cancers [49] \\
\hline 27 & ATP synthase, mitochondrial FI complex, epsilon subunit & ATP5E & \\
\hline 28 & Tumor protein, translationally-controlled I & TPTI & Involved in malignant transformation [50] \\
\hline 29 & Cytochrome c oxidase subunit Vlla polypeptide 2 & COX7A2 & \\
\hline 30 & Ubiquitin B & UBB & Related to sustained proliferation [5I] \\
\hline
\end{tabular}

oligo(dT)24 primer containing a T7 promoter sequence. After RNA template degradation and cDNA's second strand cDNA synthesis, complementary RNA (cRNA) was transcribed in vitro using biotinylated NTPs and T7 RNA polymerase. After purification using RNeasy columns (Qiagen), $18 \mu \mathrm{g}$ of biotin-labeled cRNAs were fragmented by metal-induced hydrolysis. Hybridization, staining, and scanning of microarrays were performed by the Microarray Facility Tübingen. Scanned images were processed using the Microarray Analysis Suite 5.0 (MAS 5.0; Affymetrix) and expression differences between tumor and library samples were determined by baseline comparison algorithms provided by the software. Data were further processed using Microsoft Access ${ }^{\mathrm{TM}}$ and Excel ${ }^{\mathrm{TM}}$.

\section{Authors' contributions}

JPC carried out the total tumor RNA extraction, the production of mRNA libraries, the analysis of clones, participated in the microarray analysis of RNA samples, evaluated the microarray data and drafted the manuscript. OS carried out the microarray analysis of RNA samples with the help of the Microarray Facility Tübingen. BW and
CG carried out the patient's recruitment and the tumor sample preparation. JP, BS and RT participated in the design of the study, the development of the work and helped to draft the manuscript. CG, IH, HGR and SP conceived, designed and coordinated this study. All authors read and approved the final manuscript.

\section{Acknowledgements}

JPC is supported by a "Fortüne" grant from the University of Tübingen and JP is supported by the DFG Graduiertenkollegue "Infektionsbiologie" of Tübingen.

\section{References}

I. Van der Bruggen P, Traversari C, Chomez P, Lurquin C, De Plaen E, Van den Eynde B, Knuth A, Boon T: A gene encoding an antigen recognized by cytolitic $T$ lymphocytes on a human melanoma. Science 199I, 254:1643-1647.

2. Kawakami Y, Eliyahu S, Delgado CH, Robbins PF, Rivoltini L, Topalian SL, Miki T, Rosenberg SA: Cloning of the gene coding for a shared human melanoma antigen recognized by autologous T cells infiltrating into tumor. Proc Natl Acad Sci USA 1994, 91:3515-3519.

3. Coulie PG, Brichard V, Van Pel A, Wolfel T, Schneider J, Traversari C, Mattei S, De Plaen E, Lurquin C, Szikora JP: A new gene coding for a differentiation antigen recognized by autologous cyto- 
lytic T lymphocytes on HLA-A2 melanomas. J Exp Med 1994, I 80:35-42.

4. Kawakami Y, Eliyahu S, Delgado CH, Robbins PF, Sakaguchi K, Appell E, Yannelli JR, Adema G], Miki T, Rosenberg SA: Identification of a Human Melanoma Antigen Recognized by Tumor-Infiltrating Lymphocytes Associated with in vivo Tumor Rejection. PNAS 1994, $91: 6458-6462$.

5. Brichard V, Van Pel A, Wolfel T, Wolfel C, De Plaen E, Lethe B, Coulie $P$, Boon $T$ : The tyrosinase gene codes for an antigen recognized by autologous cytolytic $T$ lymphocytes on HLAA2 melanomas. J Exp Med 1993, 178:489-495.

6. Robbins PF, el-Gamil M, Kawakami Y, Stevens E, Yannelli JR, Rosenberg SA: Recognition of tyrosinase by tumor-infiltrating lymphocytes from a patient responding to immunotherapy. Cancer Res 1994, 54:3124-3। 26.

7. Gaugler B, Van den Eynde B, van der Bruggen P, Romero P, Gaforio J], De Plaen E, Lethe B, Brasseur F, Boon T: Human gene MAGE-3 codes for an antigen recognized on a melanoma by autologous cytolytic T lymphocytes. J Exp Med 1994, 179:92।-930.

8. Chen YT, Scanlan MJ, Sahin U, Tureci O, Gure AO, Tsang S, Williamson B, Stockert E, Pfreundschuh M, Old LJ: A testicular antigen aberrantly expressed in human cancers detected by autologous antibody screening. PNAS 1997, 94:19|4-1918.

9. Marchand M, van Baren N, Weynants P, Brichard V, Dreno B, Tessier $\mathrm{MH}$, Rankin E, Parmiani G, Arienti F, Humblet Y, Bourlond A, Vanwijck R, Lienard D, Beauduin M, Dietrich PY, Russo V, Kerger J, Masucci G, Jaeger E, De Greve J, Atzpodien J, Brasseur F, Coulie PG, van der Bruggen $P, T$. B: Tumor regressions observed in patients with metastatic melanoma treated with an antigenic peptide encoded by gene MAGE-3 and presented by HLA-AI. Int J Cancer 1999, 80:219-230.

10. Cebon J, Jaeger E, Shackleton MJ, Gibbs P, Davis ID, Hopkins W, Gibbs S, Chen Q, Karbach J, Jackson H, MacGregor DP, SturrockI S, Vaughan H, Maraskovsky E, Neumann A, Hoffman E, Sherman ML, Knuth A: Two phase I studies of low dose recombinant human IL-I 2 with Melan-A and influenza peptides in subjects with advanced malignant melanoma. Cancer Immunity 2003, 3:7-25.

II. Chen Q, Jackson H, Shackleton M, Parente P, Hopkins W, Sturrock S, MacGregor D, Maraskovsky E, Tai TY, Dimopoulos N, Masterman KA, Luke T, Davis ID, Chen W, Cebon J: Characterization of antigen-specific CD8+ $T$ lymphocyte responses in skin and peripheral blood following intradermal peptide vaccination. Cancer Immunity 2005, 5:5-I2.

12. Ferrone S, Finerty JF, Jaffee EM, Nabel GJ: How much longer will tumour cells fool the immune system? Immunology Today 2000, 21:70-72.

13. Gilboa E: The makings of a tumor rejection antigen. Immunity 1999, I I:263-270.

14. Heiser A, Coleman D, Dannull J, Yancey D, Maurice MA, Lallas CD, Dahm P, Niedzwiecki D, Gilboa E, Vieweg J: Autologous dendritic cells transfected with prostate-specific antigen RNA stimulate CTL responses against metastatic prostate tumors. The Journal of Clinical Investigation 2002, 109:409-4I7.

15. Granstein RD, Ding W, Ozawa H: Induction of anti-tumor immunity with epidermal cells pulsed with tumor-derived RNA or intradermal administration of RNA. J Invest Dermatol 2000, II 4:632-636.

16. Jaeger E, Ringhoffer M, Karbach J, Arand M, Oesch F, Knuth A: Inverse relationship of melanocyte differentiation antigen expression in melanoma tissues and CD8+ cytotoxic-T-cell responses: evidence for immunoselection of antigen-loss variants in vivo. Int J Cancer 1996, 66:470-476.

17. Jaeger E, Ringhoffer M, Altmannsberger M, Arand M, Karbach J, Jager $D$, Oesch $F$, Knuth $A$ : Immunoselection in vivo: independent loss of MHC class I and melanocyte differentiation antigen expression in metastatic melanoma. Int J Cancer 1997, 71:142-147.

18. Kerkmann-Tucek A, Banat GA, Cochlovius B, Zoller M: Antigen loss variants of a murine renal cell carcinoma: implications for tumor vaccination. Int / Cancer 1998, 77: | | 4- 22.

19. Singluff CLJ, Colella TA, Thompson L, Graham DD, Skipper JC, Caldwell J, Brinckerhoff L, Kittlesen DJ, Deacon DH, Oei C: Melanomas with concordant loss of multiple melanocytic differentiation proteins: immune escape that may be overcome by targeting unique or undefined antigens. Cancer Immunol Immunother 2000, 48:66I-672.
20. Boon $T$, van der Bruggen $P$ : Human tumor antigens recognized by $T$ lymphocytes. The Journal of Experimental Medicine 1996, 1 83:725-729.

21. Jaeger E, Bernhard H, Romero P, Ringhoffer M, Arand M, Karbach J, Ilsemann $C$, Hagedorn M, Knuth A: Generation of cytotoxic Tcell responses with synthetic melanoma-associated peptides in vivo, implications for tumor vaccines with melanomaassociated antigens. Int J Cancer 1996, 66:162-169.

22. Soiffer R, Lynch T, Mihm M, Jung K, Rhuda C, Schmollinger JC, Hodi FS, Liebster L, Lam P, Mentzer S, Singer S, Tanabe KK, Cosimi AB, Duda R, Sober A, Bahn A, Daley J, Neuberg D, Parry G, Rokowich J, Richards L, Drayer J, Berns A, Clift S, Dranoff G: Vaccination with irradiated autologous melanoma cells engineered to secrete human granolucyte-macrophage colony-stimulating factor generates potent antitumor immunity in patients with metastatic melanoma. Proc Natl Acad Sci USA 1998, 95: | 3 |4 I-13 | 46.

23. Nestle FO, Alijagic S, Gilliet M, Sun Y, Grabbe S, Dummer R, Burg G, Schadendorf S: Vaccination of melanoma patients with peptide- or tumor lysate-pulsed dendritic cells. Nature 1998, 4:328-332.

24. Boczkowski D, Nair SK, Snyder D, Gilboa E: Dendritic cells pulsed with RNA are potent antigen presenting in vitro and in vivo. Journal of Experimental Medicine 1996, 184:465-472.

25. Simons JW, Mikhak B, Chang JF, DeMarzo AM, Carducci MA, Lim M, Weber CE, Baccala AA, Goemann MA, Clift SM, Ando DG, Levitsky HI, Cohen LK, Sanda MG, Mulligan RC, Partin AW, Carter HB, Piantadosi S, Marshall FF, Nelson WG: Induction of immunity to prostate cancer antigens: results of a clinical trial of vaccinated with the irradiated autologous prostate tumor cells engineered to secreted granulocyte-macrophage colony-stimulating factor using ex vivo gene transfer. Cancer Research 1999 , 59:5160-5168.

26. Kobayashi T, Yamanaka R, Homma J, Tsuchiya N, Yajima N, Yoshida $S$, Tanaka R: Tumor mRNA-loaded dendritic cells elicit tumorspecific CD8+ cytotoxic $T$ cells in patients with malignant glioma. Cancer Immunol Immunother 2003, 52:632-637.

27. Griffioen M, Borghi M, Schrier PI, Osanto S, Schadendorf D: Analysis of T-cell responses in metastatic melanoma patients vaccinated with dendritic cells pulsed with tumor lysates. Cancer Immunol Immunother 2004, 53:7I 5-722.

28. Boczkowski D, Nair SK, Nam JH, Lyerly HK, Gilboa E: Induction of tumor immunity and cytotoxic $T$ lymphocytes responses using dendritic cells transfected with messenger RNA amplified from tumor cells. Cancer Research 2000, 60:1028-1034.

29. Heiser A, Maurice MA, Yancey DR, Wu NZ, Dahm P, Pruitt SK, Boczkowski D, Nair SK, Ballo MS, Gilboa E, Vieweg J: Induction of polyclonal prostate cancer-specific CTL using Dendritic cells transfected with amplified tumor RNA. The Journal of Immunology 200I, 166:2953-2960.

30. Grünebach F, Müller MR, Nencioni A, Brossart P: Delivery of tumor-derived RNA for the induction of cytotoxic T-lymphocytes. Gene Therapy 2003, 10:367-374.

3I. Hoerr I, Obst R, Rammensee HG, Jung G: In vivo application of RNA leads to induction of specific cytotoxic $T$ lymphocytes and antibodies. European Journal of Immunology 2000, 30: I-7.

32. Seth D, Gorrell MD, McGuinness PH, Leo MA, Lieber CS, McCaugan GW, Haber PS: SMART amplification maintains representation of relative gene expression: quantitative validation by real time PCR and application to studies of alcoholic liver disease in primates. J Biochem Biophzs Methods 2003, 55:53-66.

33. Wellenreuther R, Schupp I, Consortium TGDNA, Poutska A, Wiemann S: SMART amplification combined with cDNA size fractionation in order to obtain large full-length clones. $B M C$ Genomics 2004, 5:36-44.

34. Yu J, Russell E: Structural and functional analysis of an mRNP complex that mediates the high stability of human B-globin mRNA. Molecular and Cellular Biology 2001, 21:5879-5888.

35. Wang Z, Day N, Trifillis P, Kiledjian M: An mRNA stability complex functions with poly(A)-binding protein to stabilize mRNA in vitro. Molecular and Cellular Biology 1999, 19:4552-4560.

36. Altschul SF, Gish W, Miller W, Meyers EW, Lipman DJ: Basic local alignment search tool. J Mol Biol 1990, 21 5:403-4I0.

37. Draper MP, August PR, Connolly T, Packard B, Call KM: Efficient cloning of full-length cDNAs based on cDNA size fractionation. Genomics 2002, 79:603-607. 
38. Wibe E, Paus E, Aamdal S: Neuron specific enolase (NSE) in serum of patients with malignant melanoma. Cancer Letters 1990, 52:29-31.

39. Kondoh N, Schweinfest CW, Henderson KW, Papas TS: Differential Expression of SI 9 Ribosomal-Protein, Laminin-Binding Protein, and Human Lymphocyte Antigen Class-I Messenger-Rnas Associated with Colon-Carcinoma Progression and Differentiation. Cancer Res 1992, 52:791-796.

40. Affymetrix's Eukaryotic Sample and Array Processing. :[http://www.affymetrix.com/support//downloads/manuls/ expression_s2_manual.pdf].

4I. Van Gelder RN, von Zastrow ME, Yool A, Dement WC, Barchas JD, Eberwine JH: Amplified RNA synthesized from limited quantities of heterogeneous cDNA. Proc Natl Acad Sci USA 1990 , 87:1663-1667.

42. GNF Gene Expression Atlas. :[http://expression.gnf.org/cgi-bin/ index.cgi].

43. Wang FL, Wang YB, Wong WK, Liu Y, Addivinola F], Liang $P$, Chen $L B$, Kantoff $P W$, Pardee $A B$ : Two differentially expressed genes in normal human prostate tissue and in carcinoma. Cancer Res 1996, 56:3634-3637.

44. Kroes RA, Jastrow A, McLone MG, Yamamoto H, Colley P, Kersey DS, Yong VW, Mkrdichian E, Cerullo L, Leestma J, Moskal JR: The identification of novel therapeutic targets for the treatment of malignant brain tumors. Cancer Lett 2000, 156:191-198.

45. Standal T, Borset M, Sundan A: Role of osteopontin in adhesion, migration, cell survival and bone remodeling. Exp Oncol 2004, 26:179-184.

46. Jiang HP, Lin JJ, Tao J, Fisher PB: Suppression of human ribosomal protein L23A expression during cell growth inhibition by interferon-beta. Oncogene 1997, | 4:473-480.

47. Banerjee A: Increased levels of tyrosinated alpha-, beta(III)and beta(IV)-tubulin isotypes in paclitaxel-resistant MCF-7 breast cancer cells. Biochem Biophys Res Commun 2002, 293:598-60I.

48. Adams SM, Sharp MGF, Walker RA, Brammar WJ, Varley JM: Differential Expression of Translation-Associated Genes in Benign and Malignant Human Breast-Tumors. $\mathrm{Br} J$ Cancer 1992, 65:65-71.

49. Friedman RS, Bangur CS, Zasloff EJ, Fan LQ, Wang TT, Watanabe Y, Kalos M: Molecular and immunological evaluation of the transcription factor SOX-4 as a lung tumor vaccine antigen. J Immunol 2004, I 72:33I9-3327.

50. Bommer UA, Thiele B]: The translationally controlled tumour protein (TCTP). Int J Biochem Cell Biol 2004, 36:379-385.

5I. Finch JS, Stjohn T, Krieg P, Bonham K, Smith HT, Fried VA, Bowden GT: Overexpression of 3 Ubiquitin Genes in Mouse Epidermal Tumors Is Associated with Enhanced Cellular Proliferation and Stress. Cell Growth Differ 1992, 3:269-278.

\section{Publish with Bio Med Central and every scientist can read your work free of charge}

"BioMed Central will be the most significant development for disseminating the results of biomedical research in our lifetime. "

Sir Paul Nurse, Cancer Research UK

Your research papers will be:

- available free of charge to the entire biomedical community

- peer reviewed and published immediately upon acceptance

- cited in PubMed and archived on PubMed Central

- yours - you keep the copyright
BioMedcentral 